\title{
Development Of Gunung Payung Cultural Park As One Of The Tourism Attraction In Kutuh Village South Kuta
}

\author{
Ni Nyoman Sri Astuti ${ }^{1}$, Ni Ketut Bagiastuti ${ }^{2}$ and I Ketut Suarta ${ }^{3}$ \\ ${ }^{1,2,3}$ Politeknik Negeri Bali, Indonesia \\ Email: ${ }^{1}$ nyomansriastuti@pnb.ac.id, ${ }^{2}$ ketutbagiastuti@pnb.ac.id and ${ }^{3}$ ketutsuarta@pnb.ac.id
}

\begin{abstract}
This study aims to determine what are the internal and external factors and development strategy of Gunung Payung Cultural Park as one of the tourist attraction in the village of Kutuh Kuta Selatan. This research use data collection methods are observation, interview, literature study and documentation. Data analysis techniques used in this study are SWOT analysis techniques and Qualitative Descriptive Analysis. A strategy that can be applied to the developed of Gunung Payung Cultural Park as an attraction, which offers a varied and innovative tourism products, using IT to promote tourist attraction, provide coaching and training to the community to improve the quality and quantity of human resources, seek funding for development, Establish order to maintain environmental sustainability, create rules for preserving the environment, and provide restaurant facilities to face competition with other tourism objects.
\end{abstract}

\section{Keywords- Internal and External Factors, Tourism Development, Tourist Attraction}

\section{INTRODUCTION}

One of the villages in Badung regency which is developing its area is Kutuh Village. Kutuh Village is located at the southern of Bali Island and part of South Kuta, it is about $28 \mathrm{~km}$ from the center of Denpasar with an area of $976,800 \mathrm{Ha}$. Geographically, Kutuh Village is directly adjacent to Campial Village and Sawangan Village in the east; The Indonesian Ocean to the south; Ungasan Village and Gerombong River in the West; and Jimbaran Village in the north. Location of Kutuh Village position can be said in the middle of the the island of Bali. To optimize the management,established Badan Usaha Manunggal Desa Adat based on local regulation 2014 number 01. all business units owned by Desa Adat Kutuh are expected to run with synergy with each other, and also duty to develop the existing potential to be a new business unit.

Gunung Payung Cultural Park is one of the tourist attraction which is managed by Desa Adat Kutuh and cooperate with private party has huge potential to be developed further, potency that can be developed continuously surely will be able to increase tourist interest to visit. Whether it's

the development of natural tourism potential, cultural arts attractions, and so forth. The plan of this tourist attraction will be developed into Integrated Tourism Attraction that combines nature tourism, cultural tourism, religious tourism, and also other tourist activities such as water sports, paragliding, outbound, and various activities that can be done tourists and other tourism support facilities. Later, Gunung Payung Cultural Park is expected to be an alternative choice besides Garuda Wisnu Kencana (GWK) Cultural Park. Gunung Payung Cultural Park has started to be visited by many tourists both foreign and domestic tourists, this can be seen in table 1 below: 


\section{TABLE I. NUMBER OF TOURIST VISITS TO GUNUNG PAYUNG CULTURAL PARK FROM} 2015 TO 2016

\begin{tabular}{llll}
\hline Month & $\begin{array}{l}\text { Year } \\
\mathbf{2 0 1 5}\end{array}$ & $\mathbf{2 0 1 6}$ & percent \\
& & & \\
\hline JAN. & - & 2,659 & - \\
FEB. & 2,090 & 2,786 & $\mathbf{3 3 . 3 0 \%}$ \\
MAR. & 2,726 & 2,689 & $\mathbf{- 1 . 3 6 \%}$ \\
APR. & 2,368 & 2,929 & $\mathbf{2 3 . 6 9 \%}$ \\
MEI & 3,101 & 3,051 & $\mathbf{- 1 . 6 1 \%}$ \\
JUN. & 2,297 & 1,759 & $\mathbf{- 2 3 . 4 2 \%}$ \\
JUL. & 2,634 & 3,248 & $\mathbf{2 3 . 3 1 \%}$ \\
AUG. & 2,339 & 3,611 & $\mathbf{5 4 . 3 8 \%}$ \\
SEP. & 42 & 3,430 & $\mathbf{8 0 6 6 . 6 7 \%}$ \\
OCT. & - & 3,146 & $\mathbf{-}$ \\
NOV. & - & 2,603 & $\mathbf{-}$ \\
DES. & 296 & 4,437 & $\mathbf{1 3 9 8 . 9 9 \%}$ \\
\hline TOTAL & $\mathbf{1 7 , 8 9 3}$ & $\mathbf{3 6 , 3 4 8}$ & $\mathbf{1 0 3 . 1 4 \%}$ \\
\hline
\end{tabular}

Source : Gunung Payung Cultural Park Management

Table 1 shows the data of tourist visits to tourist destination Gunung Payung Cultural Park for the last 2 years. In the table above can be seen the increase in visits from 2015 to 2016 . One of the benchmarks in the development of a tourist destination is the number of tourist visits because with the increase in tourist visits will be followed directly by the development of facilities and infrastructure support tourism. On the basis of this is the need for a study of the potential development strategy of Gunung Payung Cultural Park as a tourist attraction in the village of Kutuh, Badung regency in order to be developed optimally in accordance with local natural and cultural conditions and does not disturb the sanctity of the temple area.

Based on the backgrounds above there are two problems discussion: What are the internal and external factors of development of the Gunung Payung Cultural Park? And How is the development strategy of Gunung Payung Cultural Park as one of the Tourism Attractions in Kutuh Village?

\section{LITERATURE REVIEW}

\section{A. Development Strategy}

According Marpaung (2000: 52) strategy is a process of determining the value of choice and decision making in the utilization of resources that cause a commitment for the organization concerned to actions that lead to the future. The development of tourism aims to provide benefits both tourists and local residents. Tourism can provide a standard of living to local residents through the economic benefits gained from tourist destinations (Marpaung (2002: 19).

According to Yoeti (1997: 2-3), tourism development needs to pay attention to several aspects are:

1. Tourist

Must be known characteristics of tourists, from which country they come, age, hobbies, and on what season they travel

2. Transportation

Must be known how the transportation facilities are available to bring tourists to the destination destination.

3. Attraction 
The attractions must be contain three conditions such as: (a) something to do; (b) something to see; (c) something to buy

4. Facilities

There are supporting facilities of tourism activities such as hotels, restaurants, banks, and others

5. Information and Promotion

It is required promotion in the form of information the existence of a tourist attraction through online media and offline media.

It can be concluded that the development strategy in this research is a unified plan of activities undertaken to promote and increase tourist visits to tourist areas (tourist attraction) that has had a predetermined plan so that later will be beneficial to the government, investors and surrounding communities, especially the community in Kutuh traditional village.

\section{B. Tourist Attraction}

According to Law No. 10 of 2009, tourist attraction is described as everything that has uniqueness, convenience, and value in the form of diversity of natural wealth, culture, and man-made products that become the target or tourist visit.

According to Law No. 10 of 2009 on tourism, article (5), states that Tourism Development is conducted by means of organizing, managing, and creating new tourist objects as tourist objects and attractions, then article (6) tourist attraction is done with attention to:

1. Ability to promote the improvement of economic and socio-cultural life.

2. Religious values, customs, and values that live in society

3. Cultural preservation and environmental quality

4. The sustainability of tourism business itself.

\section{METHODS}

Data collection in this research are observation, interview, literature study and documentation. Data analysis techniques used in this research are: Descriptive Analysis and SWOT Analysis Qualitative descriptive analysis method is used to answer the problem formulation. analytical techniques used that is by describing the information obtained from data collection Trianggulasi, by comparing data obtained from interviews with managers, observations made by researchers and documents related to the problem.

\section{RESULT AND DISCUSSION}

Gunung Payung Cultural Park is a pioneering tourist area in the form of a cultural park that has been open to the public since February 2015. Located in the village of Kutuh, South Kuta District, a tourist area developed on the outside area Pura Gunung Payung by exploiting an area of about $14 \mathrm{Ha}$ of $16 \mathrm{Ha}$, added cliff area of 3 Ha. Gunung Payung Cultural Park can be reached with a distance of $20 \mathrm{~km}$ or about 35 minutes drive from Ngurah Rai International Airport. As one of the growing tourist attractions, Gunung Payung Cultural Park requires proper management and adequate funding to smooth the process of developing the object itself. Management of tourist attraction is closely related to the availability of funds owned for the development can run in accordance with the planned. The result of this research shows that the strength of Gunung Payung Cultural Park is the beautiful and natural scenery and beaches, the existence of Pura Gunung Payung, the surf and paragliding activities, the cultural arts attractions and other events in the amphitheater, the large parking area, the availability of toilets public, friendliness of the local community, easy accessibility level and strategic location. The weakness of Gunung Payung Cultural Park as a tourist attraction, are: food and beverage facilities is still simple, quality and quantity of human resources are still less, as well as budget constraints for the procurement of facilities. There are three opportunities are: the number of tourists, 
promotions and training conducted by academics, as well as advances in technology and information. The threats are the tourist concern to keep the tourist attraction well and the development of other attractions that increase competition.

\section{A. Internal Factors of Tourism Attraction Development Gunung Payung Cultural Park}

Based on the results of observations and interviews with the informants, here is an internal factor of efforts to develop Gunung Payung Cultural Park as one of the tourist attraction in Kutuh Village which includes:

1. Beautiful natural and beach

Gunung Payung beach is a white sandy beach located within the area of Gunung Payung Cultural Park

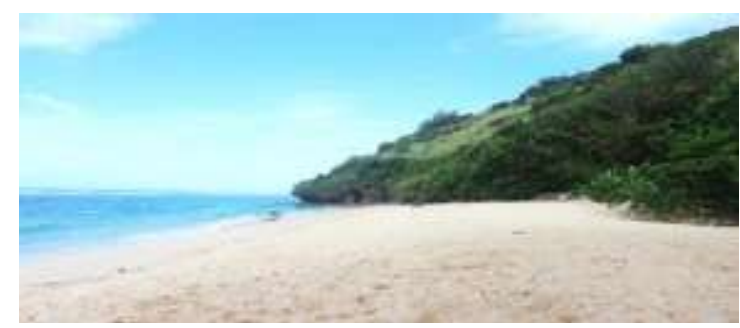

\section{Source : Private Collection of Ni Nyoman Sri Astuti \\ FIG I. GUNUNG PAYUNG BEACH}

2. Gunung Payung Temple

The beauty of its architecture, its historical value, and hundreds of monkeys around the temple area are able to attract tourists to visit

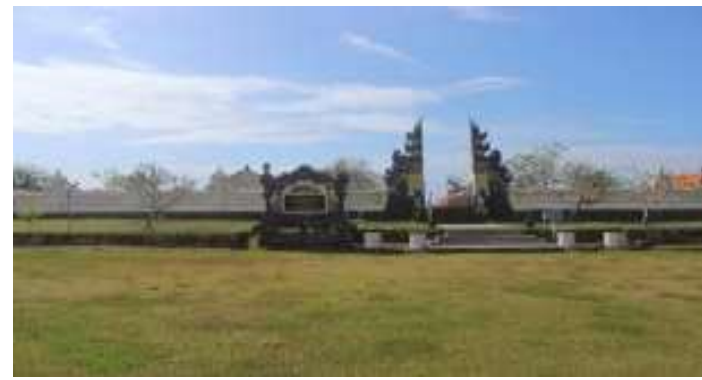

Source: Private Collection of Ni Nyoman Sri Astuti

FIG II. GUNUNG PAYUNG TEMPLE

3. Surfing and Paragliding

This paragliding activity has involved expert pilots and the Indonesian Aero Sport Federation (FASI) of Bali Province
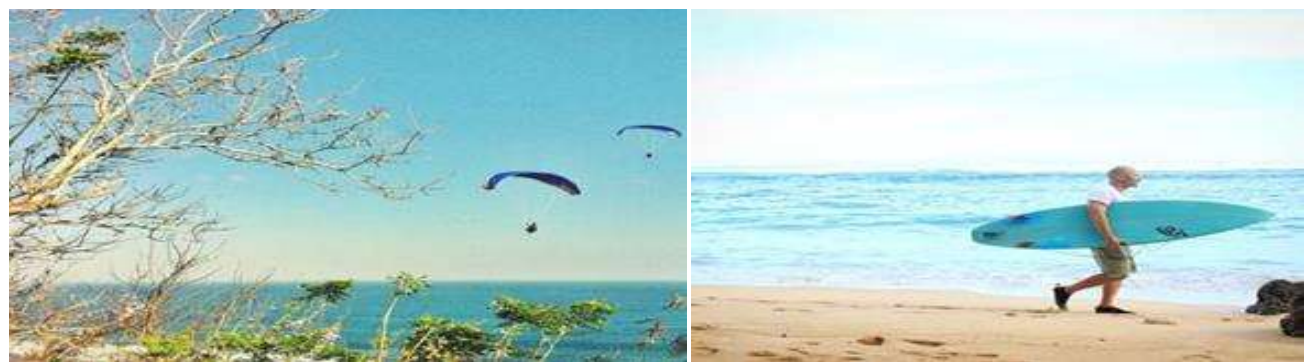

Source: Private Collection of Ni Nyoman Sri Astuti Picture

FIG III. SURFING AND PARAGLIDING ACTIVITIES 
4. Art and Culture Attraction

There is an open stage that can be used as a place of cultural arts attractions such as barong dance, kecak dance, and various other traditional dances. And can also be used for certain events, such as wedding party

5. Poor Food and Beverage Facilities

There is no good dining and drinking facilities

6. Good Public Facilities

Gunung Payung Cultural Park has several public facilities that support tourist activities during the visit, such as a large parking lot and public toilet facilities

7. Less Human Resources Quality and Quantity

The quality and quantity of human resources are still lacking

8. Good local community

The attitude of the local community there is able to provide a sense of comfort to visitors

9. Limited budget for facilities procurement

Limitations of funds make the development Gunung Payung Cultural Park to be hampered

10. Good Accessibility

Gunung Payung Cultural Park can be reached from Denpasar it is about 45 minutes and a35 from

Ngurah Rai International Airport with good road conditions.

11. Strategic Location

Located in the center of tourism area, exactly in south kuta

\section{B. External Factors of Tourism Attraction Development of Gunung Payung Cultural Park}

Based on the results of observations and interviews with the informants, the following is an external factor in the development of Gunung Payung Cultural Park as one of the tourist attraction in Kutuh Village which includes:

1. The number of tourists visiting

This can be seen from the increase in annual visits to Gunung Payung Cultural Park

2. Lack of tourist concerning to keep the tourist attraction clean

Some tourists throw garbage carelessly

3. The promotion and training from academics

Several times the training in the form of community service by educational institutions in Bali, as well as a form of promotion for the existence of GunungPayung Cultural Park.

4. Advances in information technology

Easy for potential tourists to access information about the existence of Gunung Payung Cultural Park

5. The development of other attractions that increase competition

The number of objects and tourist attraction that developed in Bali, with natural or artificial attraction makes the level of competition more difficult.

\section{SWOT Analysis As a Strategy of Tourism Development of Gunung Payung Cultural Park}

After analyzing the internal factors and external factors of development of Gunung Payung Cultural Park, it can be processed into a strategy using SWOT matrix. The formulation of the strategy is based on strengths, weaknesses, opportunities and threats, which is it van be produce into SO strategy (Strength - Opportunities), ST (Strength - Treaths) Strategy, WO (Weakness - Opportunities) Strategy and WT Strategy (Weakness - Treaths ). 


\section{TABLE II. SWOT MATRIX OF TOURISM DEVELOPMENT STRATEGYGUNUNG PAYUNG} CULTURAL PARK

\begin{tabular}{|c|c|c|}
\hline & \begin{tabular}{|l|l|} 
& STRENGTHS (S) \\
a. & Beautiful natural and beach \\
b. & Gunung Payung Temple \\
c. & Surfing and paragliding \\
& activities \\
d. & Art and Culture Attraction \\
e. & Good Public Facilities \\
f. & Good local community \\
g. & Good Accessibility \\
h. & Strategic Location
\end{tabular} & \begin{tabular}{|l} 
WEAKNESS (W) \\
a. Poor Food and Beverage \\
Facilities \\
b. Less Human Resources \\
Quality and Quantity \\
c. Limited budget for facilities \\
procurement
\end{tabular} \\
\hline EFAS & & \\
\hline $\begin{array}{l}\text { OPPORTUNITIES (O) } \\
\text { a. The number of tourists } \\
\text { visiting } \\
\text { b. The promotion and } \\
\text { training from } \\
\text { academics } \\
\text { c. Advances in } \\
\text { information technology }\end{array}$ & $\begin{array}{l}\text { SO STRATEGY } \\
\text { a. Maximize of tourist visits by } \\
\text { offering variety and innovative } \\
\text { tourism products } \\
\text { b. Used the information and } \\
\text { technology to promote the } \\
\text { tourism products }\end{array}$ & $\begin{array}{l}\text { WO STRATEGY } \\
\text { a. Providing guidance and } \\
\text { training to the community to } \\
\text { improve the quality and } \\
\text { quantity of human resources } \\
\text { b. Looking for funding sources } \\
\text { for development }\end{array}$ \\
\hline \begin{tabular}{|l} 
THREATS (T) \\
a. Lack of tourist \\
concerning to keep the \\
tourist attraction clean \\
b. The development of \\
other attractions that \\
increase competition
\end{tabular} & $\begin{array}{l}\text { ST STRATEGY } \\
\text { a. Optimizing the potential of } \\
\text { nature and cultural attractions } \\
\text { to overcome competition with } \\
\text { other tourist objects } \\
\text { b. Make the regulation to } \\
\text { maintain environmental } \\
\text { sustainability }\end{array}$ & $\begin{array}{l}\text { WT STRATEGY } \\
\text { a. Provide good food and } \\
\text { beverages facilities to face } \\
\text { competition with other } \\
\text { attractions } \\
\text { b. Improving the quality of } \\
\text { human resources to improve } \\
\text { competitiveness }\end{array}$ \\
\hline
\end{tabular}

Based on the SWOT matrix that has been created, then formulated several programs that support the development strategy of Gunung Payung Cultural Park as one of the tourist attraction in Kutuh Village, among others:

1. SO strategies (Strength and Opportunities), which are strategies that optimize the strengths to take advantage of opportunities, are:

a) maximize the high interest of tourists to visit by offering various and innovative tourism products. In addition to offering cultural arts attractions such as traditional dance, the management can also offer staging theater or sendratari

b) Using the progress of information technology to promote tourist attraction will be more effective because in this globalization era, all people can access the internet easily wherever and whenever

2. WO strategies (Weaknesses and Opportunities), which are strategies that minimize weaknesses to exploit opportunities, are: 
a) Support from academicians to help local community of Kutuh Village with a lot of training programs, especially in changing the paradigm of local community going to be competitive tourism thinking.

b) Looking for funding sources for development. With the large number of tourists to visit, it will also increase revenue from entrance tickets and consumption they do in the object. This condition allows management to obtain funds from other parties, such as funds sourced from the government, because the Government tends to more glance tourist attraction that is growing.

3. Strategy ST (Strength and Threats), the strategy that uses the strength to deal with threats, are:

a) By optimizing the potential of nature and uniqueness of cultural arts attractions that are not owned by other attractions so it can increased the competition with other tourist objects

b) Make regulation to maintain environmental sustainability. Because there are still many tourists who throw garbage carelessly, the management also provide a trash at a certain point

4. WT strategies (Weaknesses and Threats), which are strategies that minimize weaknesses and threats, are:

a) Provide culinary facilities in the tourist attraction as a tourism support facility, so it can improve competitiveness.

b) Improving the quality of human resources to face competition with other tourist objects

\section{CONCLUSIONS}

The strengthness of Gunung Payung Cultural Park is a beautiful and natural panorama of nature and beaches, the presence of Gunung Payung Temple, surf and paragliding activities, cultural arts attractions and other events in the amphitheater, vast parking area, public toilet availability, community friendliness local, easy accessibility and strategic location. The weakness of Gunung Payung Cultural Park as a tourist attractions, are : facilities that provide food and beverage is still simple, quality and quantity of human resources are still lacking, as well as budget constraints for the procurement of facilities. The opportunities are: the number of tourists who want to visit, promotions and training conducted by academics, as well as advances in technology and information. The threat of Gunung Payung Cultural Park are: poor food and beverage facilities, less human resources quality and quantity, limited budged for facilities procurement. There are several strategies that can be applied to the development of Gunung Payung Cultural Park as an attraction, which offers a varied and innovative tour products, using IT to promote tourist attraction, provide coaching and training to the community to improve the quality and quantity of human resources, developing, creating regulation to preserve the environment, and providing restaurant facilities to face competition with other tourism object.

\section{REFERENCES}

Anonim, (2009). Undang-Undang RI Nomor 10 Tahun 2009 tentang Kepariwisataan.

Lugraha, I Wayan.( 2012). Spiritualisme Di Kaki Bali. Desa Adat Kutuh:Desa Pekraman Kutuh Bekerja Sama dengan Buku Arti

Marpaung, Happy. (2002). Pengantar Pariwisata. Bandung : Alfabeta.

Pendit, Nyoman. (2002). Ilmu Pariwisata: Sebuah Pengantar Perdana. Jakarta: PT Pradnya Paramiata.

Sugiyono.(2014). Metode Penelitian Kuantitatif, Kualitatif, dan R\&D. Bandung: ALFABETA

Utama dan Mahadewi.2012. Metodelogi Penelitian Pariwisata \& Perhotelan. Yogjakarta: ANDI 